\title{
Palatability Tests on Giant Pangola grass (Digitaria valida Stent) and Signal grass (Brachiaria brizantha) as compared with Napier (Merker) grass (Pennisetum purpureum)
}

\author{
L. Rivera Brenes, J. A. Arroyo, H. Cestero, and A. Sierra ${ }^{1}$
}

INTRODUCTION

Signal grass (Brachiaria brizantha) and Giant Pangola grass (Digitaria valida Stent) were introduced into Puerto Rico by the Agricultural Experiment Station during the course of the year 1957. The first was introduced from Ceylon and the second from Cuba. Signal grass is widely used in Ceylon and Giant Pangola grass is planted in Cuba, but we do not know to what extent. No technical literature has been received from Cuba on this grass.

Napier grass is very palatable $(3)^{2}$ and is used for comparison purposes.

Unpublished data of this Station on yield per acre (4) indicate that both Signal and Giant Pangola compare favorably with other forage grasses in the Island.

A palatability test was made after obtaining preliminary information on the behavior of these grasses in the field, and before further and more extensive experimentation is conducted. The results of this trial are reported here.

\section{PROCEDURE}

The experiment performed to compare the relative palatabilities of the three grasses was set up using a $3 \times 3$ Latin-square design with a 7-day prefeeding period and a 7-day collection period (1). Three animals were used per group. The grasses were fertilized at the rates of 400 pounds of $\mathrm{N}$, 300 of $\mathrm{P}_{2} \mathrm{O}_{5}$, and 300 of $\mathrm{K}_{2} \mathrm{O}$ per acre per year. They were cut starting at an age between 40 to 50 days when they were green and tender.

Early in the morning each day enough grass was cut from each plot to feed the corresponding group. The grasses were chopped in a silage-chopper in the barn where the animals were. Samples were taken for the determination of moisture content and calculation of dry-matter intake. Digestibility

1 Animal Husbandman, Head of Department; Assistant Chemist; Assistant Animal Husbandman; and Assistant Agronomist, respectively, of the Gurabo Substation, Agricultural Experiment Station of the University of Puerto Rico, Río Piedras P.R.

${ }^{2}$ Italic numbers in parentheses refer to Literature Cited. p. 150. 
determinations were also made; information on the results of these determinations is reported separately.

Open, dry cows and 2-year-old heifers were used for the experiment. They were weighed every morning during the collection periods. Total consumption was measured every day. Forages were offered to the animals in three or four servings during the day. At night they were put out in an exercise lot where they had access only to water. Both fresh-material and dry-matter consumption were calculated per 100 pounds of live weight for uniformity. Chemical analyses were made according to the A.O.A.C. Official Methods. The data were statistically analyzed.

TABLE 1.-Crude-protein and dry-matter contents (percent) of the 3 grasses, average of all trials

\begin{tabular}{|c|c|c|c|}
\hline Grass & Crude protein & Dry matter & \\
\hline $\begin{array}{l}\text { Napier } \\
\text { Giant Pangola } \\
\text { Signal }\end{array}$ & $\begin{array}{l}6.63 \\
5.93 \\
5.39\end{array}$ & $\begin{array}{l}16.58 \\
21.32 \\
22.51\end{array}$ & $\begin{array}{l}1 \\
\vdots \\
\vdots \\
\vdots\end{array}$ \\
\hline
\end{tabular}

\section{RESULTS AND DISCUSSION}

Data for the average pounds of fresh forage and dry matter per 100 pounds of live weight consumed from each grass are presented in the following tabulation:

\begin{tabular}{cc}
\multicolumn{2}{c}{ Napier grass } \\
\hline Fresh forage & Dry maller \\
11.77 & 1.89
\end{tabular}

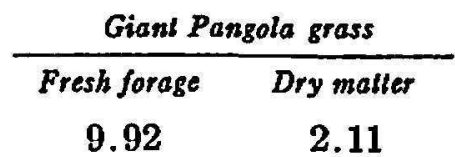

\begin{tabular}{cc}
\multicolumn{2}{c}{ Signal grass } \\
\hline Fresh forage & Dry maller \\
8.70 & 1.95
\end{tabular}

The average chemical analyses for crude protein and dry matter are given in table 1. Napier grass is higher in protein content but much lower in dry matter than Giant Pangola and Signal grasses.

As shown in the tabulation the animals consumed more fresh Napier grass, but because the dry-matter content of the other two grasses was higher, the intake of dry matter was essentially the same for the three.

Statistical analyses presented in table 2 showed no significant difference between the grasses either for fresh-material or for dry-matter intake.

The two new grasses are as palatable as Napier with the advantage over it that the animals ingest more dry matter per pound of fresh forage eaten. This is a very important factor in cattle nutrition in Puerto Rico where hay is not used and it is difficult for our cattle to ingest large amounts of dry matter from our common forages which have a very high moisture content. 
Figure 1 presents the dry-matter consumption by a 900-pound cow on Napier, Giant Pangola, and Signal grasses. According to Morrison Standards (2) a 900-pound cow needs from 6.4 to 7.2 pounds of T.D.N. for maintenance. Assuming 50-percent T.D.N. for the dry matter consumed in the forages under test, all three grasses rated far over Morrison's high limit. Giant Pangola was somewhat higher than the other two.

TABLE 2.-Results of the statistical analyses on palatability as pounds of green roughage and dry matter consumed per $100 \mathrm{lb}$. of live weight for the 3 grasses

\begin{tabular}{l|r|r|r|r|r|r|r|r}
\hline \multirow{2}{*}{$\begin{array}{l}\text { Source of } \\
\text { variance }\end{array}$} & \multicolumn{4}{|c|}{ Green forage } & \multicolumn{4}{|c}{ Dry matter } \\
\cline { 2 - 9 } & D.F. & S.S. & M.s. & F. & D.F. & S.S. & M.S. & F. \\
\hline Total & 8 & 30.06 & & & 8 & 0.17 & & \\
Periods & 2 & 8.77 & & & 2 & .04 & & \\
Groups & 2 & 4.51 & & & 2 & .03 & & \\
Grasses & 2 & 14.37 & 7.19 & $5.94^{1}$ & 2 & .08 & 0.04 & $4.00^{1}$ \\
Error & 2 & 2.41 & 1.21 & & 2 & .02 & .01 & \\
\hline
\end{tabular}

1 Not significant.

Dry matter (pounds)

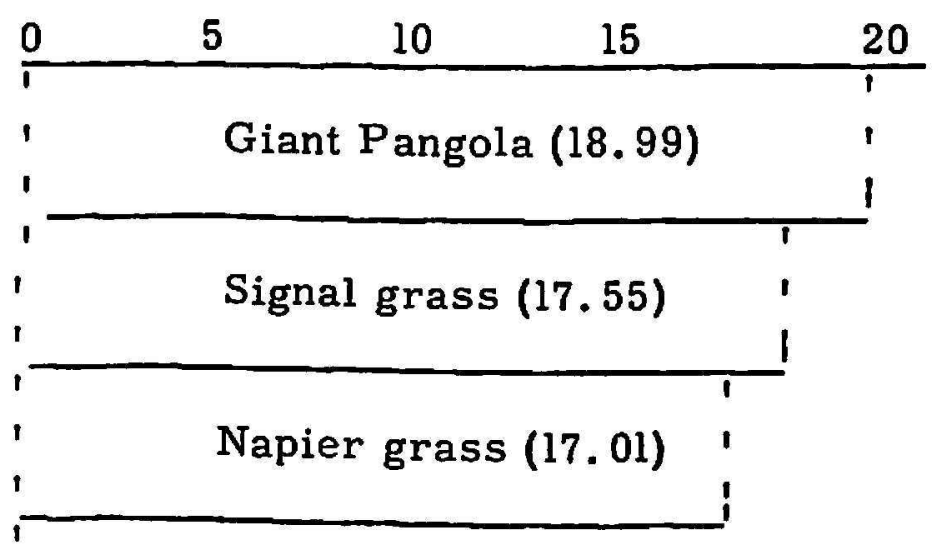

Fig. 1.-Dry-matter consumption by a 900-pound cow of Giant Pangola grass, Signal grass, and Napier grass.

\section{SUMMARY AND CONCLUSIONS}

Signal grass (Brachiaria brizantha) and Giant Pangola (Digitaria valida Stent) were introduced into Puerto Rico by the Agricultural Experiment Station in 1957, from Ceylon and Cuba, respectively. Field observations and unpublished data on yields indicate good forage possibilities for these grasses for the Island.

Both were submitted to a palatability test and compared with Napier grass, (Pennisetum purpureum), which is one of our most palatable forage 
grasses, using a $3 \times 3$ Latin-square design. The two grasses are as palatable as and contain more dry matter per pound of green forage than Napier grass.

Both grasses are under grazing trials and must be submitted to more field observations before final recommendations are given to the farmers.

\section{RESUMEN}

En 1957, la Estación Experimental Agrícola de la Universidad de Puerto Rico introdujo la yerba Estación (Brachiaria brizantha) de Ceylán y la Pangola Gigante (Digitaria valida Stent) de Cuba. Las observaciones de campo y datos de rendimientos, aún sin publicar, indican que estas yerbas son buenas para forraje y por lo tanto prometedoras. Ambas se han sometido a pruebas para determinar hasta qué grado las apetece el ganado, en comparación con la yerba Napier (Merker), la cual es una de las más apetecidas. Los resultados de estas pruebas, en las cuales se usó el cuadrado latino $3 \times 3$, han demostrado que ambas yerbas son tan apetecidas por el ganado como la Napier (Merker) y contienen más materia seca por libra de forraje verde que ésta.

Actualmente, ambas yerbas están en prueba de pastoreo para lo cual se continuarán las observaciones. No se hará una recomendación definitiva a los agricultores sobre la conveniencia de sembrar comercialmente estas yerbas hasta haber recogido y analizado todos los experimentos que se están llevando a cabo.

\section{LITERATURE CITED}

1. Anonymous, Summary of proceedings of a conference held at Beltsville, Md., Feb. 20-21, 1956, on Procedures and Technics Used in Silage Studies, USDA, Washington, D.C., L. A. Moore, Chairman.

2. Morrison, F. B., Feeds and Feeding, The Morrison Publishing Co., Ithaca, N.Y., Feb. 22, 1956.

3. Rivera Brenes, L., Herencia, J., Arroyo, J. A., and Cabrera, J. I., Palatability trials on Merker grass (Pennisetum purpureum), Venezuela grass (Paspalum fasciculatim), and plaintain pseudostalks (Musa paradisiaca), J. Agr. Univ. P.R. 43(4), 249-54, 1959.

4. Sotomayor, A., Personal communication of unpublished data on fieldwork with the grasses used in our work, Genetics Dept., Agr. Exp. Sta., Rio Piedras, P.R., 1960. 